\title{
RANCANG BANGUN APLIKASI KEPEGAWAIAN PEGAWAI NEGERI SIPIL DAN PEGAWAI HONORER PADA BADAN KEPEGAWAIAN DAN DIKLAT KABUPATEN
}

\author{
Gerry Aris Munandar ${ }^{1)}$, Amarudin ${ }^{2)}$ \\ ${ }^{1), 2)}$ Informatika, Universitas Teknokrat Indonesia \\ Jl. H.ZA Pagaralam, No 9-11, Labuhanratu,Bandarlampung \\ Email : hokhy_banget@yahoo.com ${ }^{1)}$, amarudin@tekknokrat.ac.id ${ }^{2)}$
}

\begin{abstract}
Abstrak
Pengelolaan data administrasi kepegawaian dalam suatu organisasi maupun instansi memegang peranan penting dalam proses administrasi. Dalam hal ini sistem administrasi kepegawaian menjadi salah satu faktor yang berpengaruh Badan Kepegawaian dan Diklat Kabupaten Pesawaran, sehingga sangat diharapkan proses pengelolaan administrasi kepegawaian dalam pelayanan pengajuan dapat dilakukan dengan cepat dan efisien. Dengan adanya perancangan sistem administrasi kepegawaian berbasis web dapat memudahkan admin dalam penginputan data administrasi, mengurangi waktu yang cukup lama, memperkecil kemungkinan terjadinya kesalahan dalam pencatatan dan mempercepat proses pencarian.
\end{abstract}

Implementasi Berdasarkan Analisis PIECES (Performance, Information, Economy, Control, Efficiency dan Service) sistem administrasi kepegawaian berbasis web ini dibuat dengan menggunakan bahasa pemrograman Delphi 7 dan database MySQL. Rancangan menggunakan UML (Unified Modelling Language) seperti Use Case Diagram, Class Diagram, Squence Diagram dan Activity Diagram. Metode pengembangan sistem yang digunakan adalah metode waterfall.

Hasil rancang bangun aplikasi kepegawaian pegawai negeri sipil dan pegawai honorer, dapat membantu admin dalam pengelolaan data administrasi kepegawaian. Mengelola data pengajuan administrasi. Melalui proses pengajuan administrasi tersebut dapat menghasilkan laporan dan surat pengantar, menyimpan data administrasi ke dalam basis data MySQL secara mudah dan cepat sekaligus mengamankan data administrasi tersebut agar tidak bisa diakses semua orang.

Kata kunci : Rancangan, Administrasi, Kepegawaian, Delphi 7.

\section{Pendahuluan}

Menurut peraturan Pemerintah Republik Indonesia nomor 23 th 2014 Pembangunan aparatur pemerintahan diarahkan untuk makin terwujudnya keberhasilan dalam mencapai pembangunan yang mensejahterakan masyarakat. Untuk itu dukungan administrasi negara yang mampu menjamin kelancaran dan keterpaduan tugas dan fungsi penyelanggaraan pemerintahan negara dan pembangunan untuk mewujudkan sistem administrasi negara yang handal, profesional, efektif dan efisien serta tanggap dengan kondisi masyarakat dalam dinamika pembangunan. Dalam upaya peningkatan sumber daya aparatur pemerintahan negara agar mampu mendukung tugas pada bidangnya maka hendaklah diciptakan pegawai yang mempunyai keterampilan yang handal serta didukung oleh aplikasi yang dapat membantu kinerja pegawai sehingga dalam menjalankan tugasnya dapat dilakukan dengan cepat dan efisien.

Badan Kepegawaian dan Diklat (BKD) Kabupaten Pesawaran merupakan salah satu aparatur pemerintahan yang terletak di Komplek Perkantoran Pemerintah Kabupaten Pesawaran J1. Raya Kedondong Binong Desa Waylayap Gedong Tataan. Badan Kepegawaian dan Diklat (BKD) Kabupaten Pesawaran memiliki empat bidang yaitu bidang dokumentasi dan kesejahteraan pegawai, bidang mutasi dan kepangkatan, bidang pengadaan dan pengembangan serta bidang pendidikan dan pelatihan.

Sampai saat ini Badan Kepegawaian dan Diklat (BKD) Kabupaten Pesawaran, masih menggunakan aplikasi microsoft excel dan pengarsipan secara manual yaitu disimpan ke dalam map dan ordner/binder. Hal ini berdampak pada kurang efektif dan efisien, karena membuat petugas (admin) kesulitan untuk mencari kembali data-data yang diperlukan dan mengontrol keamanan data karena berkas tersebut bisa diakses oleh siapa saja. Kehilangan data, kesalahan pendataan dapat mengakibatkan data yang terdahulu tertimpa dengan data yang baru menjadi masalah yang harus diatasi.

\subsection{Rumusan Masalah}

Berdasarkan penjabaran latar belakang maka dapat diambil rumusan masalah yaitu:

1. Pada peroses pendataan Pegawai Negeri Sipil (PNS) dan Pegawai Honorer masih dilakuakan secara manual, sehingga menyebabkan lambat dalam pengimputan di dalam proses pelayanan Pegawai Negeri Sipil (PNS) dan Pegawai Honorer dalam pembuatan laporan dan kegiatan lainnya yang saling berhubungan.

2. Proses pendataan Pegawai Negeri Sipil (PNS) dan Pegawai Honorer pada Badan Kepegawaian dan Diklat Kabupaten Pesawaran belum memiliki sistem aplikasi data yang program dengan baik jadi masih banyak penyimpanan data yang tidak teratur dan terdapatnya beberapa data yang sama.

\subsection{Batasan Masalah}

Adapun batasan pembahasan dalam penelitian ini adalah: 
3. Pembahasan fokus pada peroses pendataan Pegawai Negeri Sipil (PNS) dan Pegawai Honorer.

4. Proses pembenahan penyimpanan data pendataan Pegawai Negeri Sipil (PNS) dan Pegawai Honorer pada Badan Kepegawaian dan Diklat Kabupaten Pesawaran yang belum teratur.

\subsection{Tujuan Penelitian}

Tujuan dari penelitian ini adalah :

1. Merancang sistem aplikasi pendataan Pegawai Negeri Sipil (PNS) dan Pegawai Honorer menggunakan Basis Data Sehingga penyimpanan data dapat terstruktur.

2. Menghasilkan sistem aplikasi pendataan Pegawai Negeri Sipil (PNS) dan Pegawai Honorer untuk Badan Kepegawaian dan Diklat Kabupaten Pesawaran dengan menggunakan bahasa pemograman borland delphi 7.

\section{Metodologi Penelitian}

\subsection{Objek Penelitian}

Penelitian ini dilakukan di Badan Kepegawaian dan Diklat Kabupaten Pesawaran.

\subsection{Jalannya Penelitian}

Metode pengumpulan data yang dipakai dalam penelitian ini untuk memperoleh data-data penelitian meliputi:

1. Pengamatan (Observasi)

Pada penelitian ini dilakukan di BKD Pesawaran terhitung mulai tanggal 1 Agustus 2014 sampai dengan tanggal 14 September 2014. Pengamatan dilakukan secara langsung terhadap sistem berjalan dan kendala atau masalah yang ada.

2. Studi Pustaka (Study library)

Studi pustaka didapat dari penelitian-penelitian serupa yang pernah dilakukan sebelumnya guna mendukung penelitian ini. Selain dari penelitian sebelumnya yang berupa jurnal juga diambil dari buku-buku yang mendukung penelitian.

3. Wawancara

Metode ini dilakukan untuk mengumpulkan data dengan cara melakukan tanya jawab/ interview secara langsung yang dilakukan kepada Kepala BKD Pesawaran untuk mendaptkan data yang diperlukan. Data yang didapatkan berupa alur sistem berjalan dan kelemahan sistem yang sedang berjalan.

\subsection{Alat Penelitian}

Dalam mengembangkan sistem ini diperlukan software dan hardware sebagai penunjang kebutuhan pembuatan sistem tersebut diantaranya:

\subsubsection{Perangkat Keras (Hardware)}

Perangkat keras (hardware) yang digunakan dalam penelitian ini adalah sebagai berikut :

1. Processor Intel Core i3

2. Memory RAM 2 GB

3. Harddisk $500 \mathrm{~GB}$

4. Monitor dengan resolusi 1366 x 768 pixels

5. Keyboard
6. Mouse
7. Kabel UTP
8. Konektor RJ 45

\subsubsection{Perangkat Lunak (Software)}

Perangkat lunak yang digunakan dalam penelitian ini adalah sebagai berikut :

1. Sistem Operasi Microsoft Windows 7 Ultimate

2. Borland Delphi 7

3. SQL Server 2000

4. Crystal report 8.5

\subsection{Tahapan Penelitian}

Sistem informasi pengolahan data kenaikan pangkat pegawai negeri sipil pada Badan Kepegawaian dan Diklat Kabupaten Pesawaran dianalisa dengan menggunakan analisis PIECES (Performance, Information, Economic, Control, Efficiency, and Service) sebagai dasar untuk memperoleh pokok-pokok permasalahan yang lebih jelas dan spesifik. Kemudian berdasarkan hasil analisa ini nantinya dapat dirancang usulan-usulan untuk diterapkan dalam sistem yang baru.

\section{Analisis Kinerja (Performance)}

Sangat berkaitan dengan peningkatan terhadap kinerja (hasil kerja). Sistem Informasi yang baru menjadi lebih efektif dan lebih cepat dalam peng-input-an dan dalam membuat laporan. Dalam hal ini sistem informasi yang berjalan kurang memberikan kinerja yang maksimal, karena sistem informasi pengolahan datanya dilakukan dengan program microsoft excel, sehingga memerlukan waktu yang cukup lama sekitar 5 - 10 menit dalam pembuatan laporan atau rekapitulasi baik secara periodik maupun secara berkala.

\section{Analisis Informasi (Information)}

Dalam penyajian informasi sering terjadi keterlambatan bahkan kesalahan-kesalahan informasi yang diberikan mengakibatkan kesalahan laporan. Penyimpanan data masih menggunakan program microsoft excel dan berkas masih dalam bentuk arsiparsip, mengakibatkan informasi yang diberikan kepada pimpinan terjadi kerusakan atau kehilangan berkas dalam bentuk arsip tersebut.

\section{Analisis Ekonomi (Economy)}

Persoalan ekonomi berkaitan dengan masalah biaya dan manfaat. Dengan adanya kelemahan-kelemahan yang ada pada aplikasi yang lama maka akan mungkin terjadi biaya yang tidak dapat diramal atau dikenal. Pengembangan aplikasi diharapkan dapat memberikan banyak manfaat dan ketidak efisienan biaya yang terjadi bisa diminimalisasi sekecil mungkin.

\section{Analisis Pengendalian (Control)}

Kontrol atau pengendalian dalam sebuah sistem informasi sangat diperlukan yaitu untuk menghindari dan mendeteksi secara dini terhadap kesalahan-kesalahan yang terjadi serta untuk menjamin keamanan data atau informasi. Dengan adanya pengendalian maka tugas-tugas atau kinerja yang mengalami gangguan bisa diatasi. 
Media penyimpanan masih belum terproteksi dengan baik dan belum adanya batasan hak akses/ pengguna aplikasi.

\section{Analisis Efisiensi (Efficiency)}

Efisiensi berhubungan dengan bagaimana sumber daya tersebut digunakan secara optimal meliputi waktu, biaya, dan peralatan sehingga tidak terjadi pemborosan. Dengan adanya analisis ini ada upaya untuk meningkatkan efisiensi dalam operasional dengan menggunakan sumber daya yang tersedia. Tidak dapat dipungkiri lagi kalau tingkat ketelitian dan kemampuan manusia cukup terbatas sedangkan pengolahan data dan laporan masih mengandalkan pada kemampuan manusia. Hal ini dapat mengakibatkan kesalahan dalam pengolahan data yang masih dilakukan dengan menggunakan program microsoft excel menyebabkan efisiensi dari sistem ini masih kurang dan kesalahan dalam pencatatan double.

\section{Analisis Pelayanan (Service)}

Peningkatan terhadap pelayanan yang diberikan oleh sistem informasi berhubungan dengan kepuasan dari user dan juga kepuasan dari masyarakat yang mendapat pelayanan. Pelayanan dari segi informasi mempunyai sasaran baik bagi pihak pemerintah, pegawai maupun masyarakat yang membutuhkan. Koordinasi yang belum teratur mengenai pengolahan data, penyimpanan laporan serta dokumentasi akan menurunkan kualitas pelayanan yang pada akhirnya akan mengakibatkan kerja dari bagian tersebut menjadi terganggu sehingga pelayanan perlu ditingkatkan.

\subsection{Desain}

Membagi kebutuhan perangkat keras dan perangkat lunak dilakukan pada tahap ini. Dengan demikian dapat menghasilkan arsitektur sistem. Pada tahapan ini peneliti menggambarkan alur sistem ke tahap perancangan sistem menggunakan Use Case Diagram, Class Diagram, dan Sequence Diagram yang detail sehingga memberikan kemudahan dalam pengimplementasikan kedalam bahasa pemograman.

\section{a) Use Case Diagram}

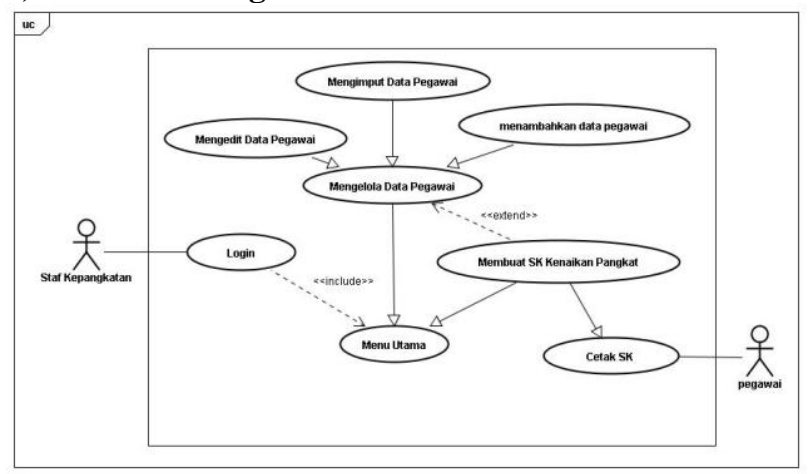

Gambar 3.3. Diagram Activity Admin

\section{b) Perancangan Aplikasi}

\section{b.1 Perancangan Form Menu Utama}

Menu utama dimaksudkan untuk memudahkan pengguna mengakses semua form pengolahan data. Untuk masuk ke menu utama diharuskan berhasil melakukan login terlebih dahulu.

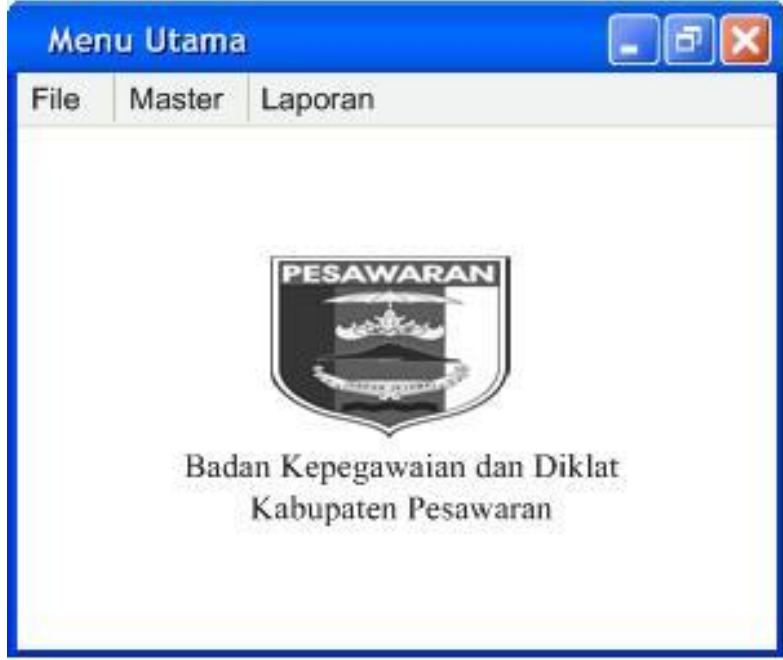

Gambar 3.6. Rancangan Form Menu Utama

\section{b.2 Perancangan Form Login}

Form login merupakan langkah awal untuk masuk kemenu utama program yaitu dengan mengisi identitas pengguna dan password. Jika identitas atau password tidak benar maka form login akan ditutup.

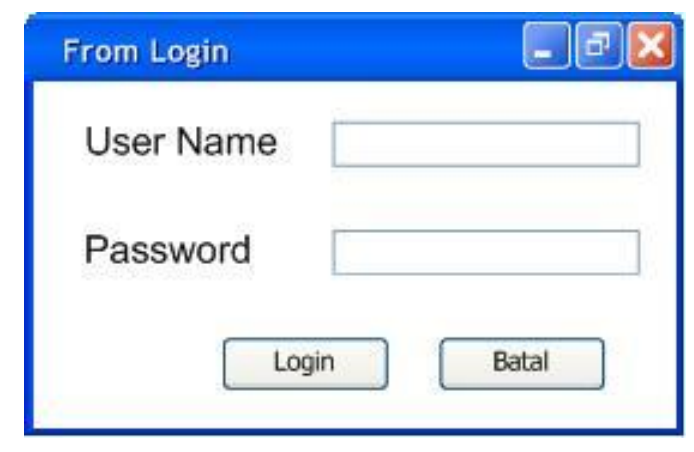

Gambar 3.7. Rancangan Form Login

\section{b.3 Perancangan Form Pegawai}

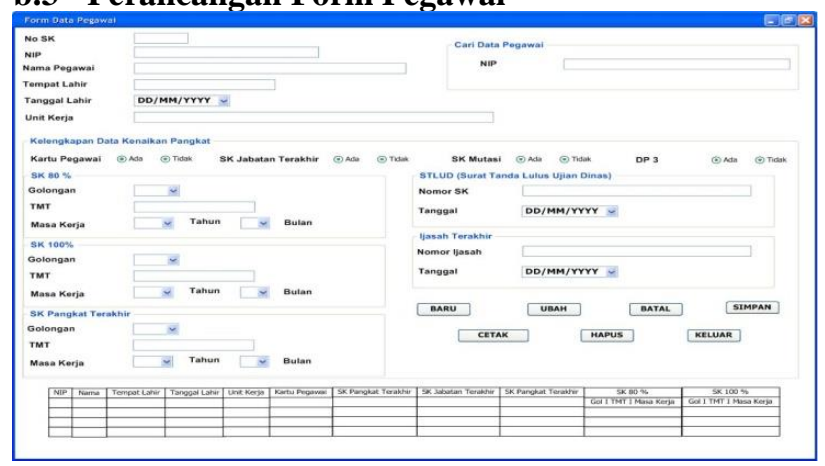

Gambar 3.8. Rancangan Form Pegawai 


\section{b.4 Form SK Kenaikan Pangkat}

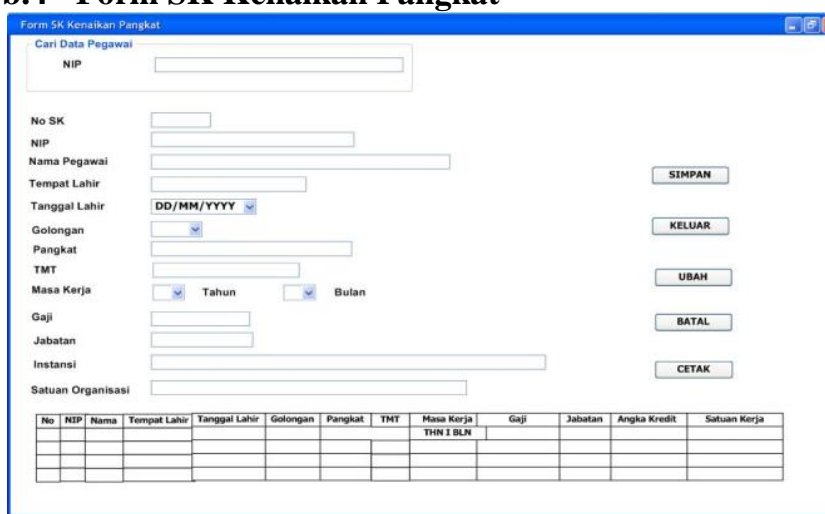

Gambar 3.9. Rancangan Form Kenaikan Pangkat

\section{b.5 Pembuatan Kode Program}

Setelah desian kemudian dilakukan pengkodean program pada tahap ini peneliti mengimplementasikan hasil dari desian ke dalam bahasa pemograman Delphi 7 dengan database MySQL. Setelah pengkodean selesai dilakukan testing/running.

\section{b.6 Pengujian (Testing)}

Setelah tahap coding selesai dibuat, testing merupakan tahapan selanjutnya yang harus dilakukan dalam pembuatan sistem informasi pengolahan data kenaikan pangkat. Metode testing yang digunakan adalah metode ujicoba blackbox. Metode ujicoba blackbox memfokuskan pada keperluan fungsional dari aplikasi. Blackbox merupakan pengujian dengan metode tes dari persfektif eksternal, tidak ada informasi mengenai struktur internal software atau aplikasi baik desain maupun source code program. Fungsi testing ini adalah untuk mengetahui kemungkinan terjadinya kesalahan dan untuk memastikan fungsi-fungsi yang terdapat dalam aplikasi berjalan dengan baik.

\section{Tabel 1. Hasil Pengujian Black-Box}

\begin{tabular}{|c|c|c|c|c|}
\hline NO & TEST CASE & $\begin{array}{c}\text { HASIL } \\
\text { HARAPAN }\end{array}$ & $\begin{array}{c}\text { HASIL } \\
\text { KELUARAN }\end{array}$ & $\mathrm{KET}$ \\
\hline \multirow[t]{2}{*}{1} & \multirow{2}{*}{$\begin{array}{l}\text { Menginput } \\
\text { data } \\
\text { login } \\
\text { dengan } \\
\text { benar }\end{array}$} & \multirow{2}{*}{$\begin{array}{l}\text { Sistem } \\
\text { menerima } \\
\text { data login } \\
\text { dan tampil } \\
\text { form data } \\
\text { pegawai }\end{array}$} & $\begin{array}{l}\text { Jika } \\
\text { sesuai } \\
\text { harapan }\end{array}$ & Sukses \\
\hline & & & $\begin{array}{l}\text { Tidak } \\
\text { sesuai } \\
\text { harapan }\end{array}$ & Gagal \\
\hline \multirow[t]{2}{*}{2} & \multirow{2}{*}{$\begin{array}{l}\text { Mengimput } \\
\text { data } \\
\text { login } \\
\text { dengan } \\
\text { salah }\end{array}$} & \multirow{2}{*}{$\begin{array}{l}\text { Sistem } \\
\text { menolak } \\
\text { akses login } \\
\text { dan disuruh } \\
\text { memasukan } \\
\text { data dengan } \\
\text { benar }\end{array}$} & $\begin{array}{l}\text { Jika } \\
\text { sesuai } \\
\text { harapan }\end{array}$ & Sukses \\
\hline & & & $\begin{array}{l}\text { Tidak } \\
\text { sesuai } \\
\text { harapan }\end{array}$ & Gagal \\
\hline \multirow[t]{2}{*}{3} & \multirow[t]{2}{*}{$\begin{array}{l}\text { Input } \\
\text { semua } \\
\text { input } \\
\text { yang ada } \\
\text { dalam } \\
\text { form }\end{array}$} & \multirow{2}{*}{$\begin{array}{l}\text { Menyimpan } \\
\text { data dan } \\
\text { menampilkann } \\
\text { ya dalam } \\
\text { grid serta } \\
\text { tidak } \\
\text { menyimpan } \\
\text { apabila } \\
\text { semua form } \\
\text { tidak di }\end{array}$} & $\begin{array}{l}\text { Jika } \\
\text { preview } \\
\text { data } \\
\text { terlihat } \\
\text { dalam } \\
\text { grid }\end{array}$ & Sekses \\
\hline & & & $\begin{array}{l}\text { Jika } \\
\text { preview } \\
\text { data } \\
\text { tidak } \\
\text { terlihat }\end{array}$ & Gagal \\
\hline
\end{tabular}

\begin{tabular}{|c|c|c|c|c|}
\hline No & TEST CASE & $\begin{array}{l}\text { HASIL } \\
\text { HARAPAN }\end{array}$ & $\begin{array}{c}\text { HASIL } \\
\text { KELUARAN }\end{array}$ & KET \\
\hline & & entri & $\begin{array}{l}\text { dalam } \\
\text { grid }\end{array}$ & \\
\hline \multirow[t]{2}{*}{4} & \multirow[t]{2}{*}{$\begin{array}{l}\text { Input NIP } \\
\text { pada } \\
\text { kenaikan } \\
\text { pangkat } \\
\text { di tahun } \\
\text { yang sama }\end{array}$} & \multirow[t]{2}{*}{$\begin{array}{l}\text { Penolakan } \\
\text { karena sudah } \\
\text { ikut serta } \\
\text { dalam } \\
\text { kenaikan } \\
\text { pangkat }\end{array}$} & $\begin{array}{l}\text { Jika } \\
\text { muncul } \\
\text { pesan } \\
\text { bahwa } \\
\text { NIP } \\
\text { sudah } \\
\text { ikut } \\
\text { serta }\end{array}$ & Sukses \\
\hline & & & $\begin{array}{l}\text { Jika } \\
\text { tidak } \\
\text { muncul } \\
\text { pesan } \\
\text { bahwa } \\
\text { NIP } \\
\text { sudah } \\
\text { ikut } \\
\text { serta }\end{array}$ & Gagal \\
\hline \multirow[t]{2}{*}{5} & \multirow[t]{2}{*}{$\begin{array}{l}\text { Menu } \\
\text { keluar }\end{array}$} & \multirow[t]{2}{*}{$\begin{array}{l}\text { Keluar dari } \\
\text { aplikasi }\end{array}$} & $\begin{array}{l}\text { Jika } \\
\text { Sesuai } \\
\text { harapan }\end{array}$ & Sukses \\
\hline & & & $\begin{array}{l}\text { Tidak } \\
\text { Sesuai } \\
\text { harapan }\end{array}$ & Gagal \\
\hline
\end{tabular}

\section{b.7 Pendukung (support) atau pemeliharaan} (maintenance)

Tahap ini tidak dilakukan karena keterbatasan waktu dan kebijakan instansi.

\section{b.8 Fase Evaluasi}

Evaluasi Aplikasi Menggunakan Black-Box Testing

Tabel 2. Lembar Uji Coba Input Sistem (1)

\begin{tabular}{|c|c|c|c|}
\hline \multirow{2}{*}{$\begin{array}{c}\text { Nama Form } \\
\text { Input }\end{array}$} & \multirow{2}{*}{ Pengamatan } & \multicolumn{2}{|c|}{ Kesimpulan } \\
\hline & & Ya* & Tidak* \\
\hline $\begin{array}{ll}\text { 1. } & \text { Form } \\
& \text { Login }\end{array}$ & $\begin{array}{l}\text { Dapat masuk ke form utama } \\
\text { untuk pengguna yang sudah } \\
\text { ditentuhkan hak akses, } \\
\text { dengan lengkap dan benar } \\
\text { dan berfungsi sesuai } \\
\text { dengan yang diharapkan, } \\
\text { apa bilia salah mesakukan } \\
\text { password atau user maka } \\
\text { akan ada pemberitauan } \\
\text { dari sistem. }\end{array}$ & $\checkmark$ & \\
\hline $\begin{array}{ll}\text { 2. } & \text { Form } \\
& \text { Menu } \\
\text { Utama } & \text { User }\end{array}$ & $\begin{array}{l}\text { Dapat tersimpan jika } \\
\text { semua data yang di-input } \\
\text { terisi dengan benar } \\
\text { tetapi jika data ada yang } \\
\text { kosong maka data tidak } \\
\text { dapat tersimpan data ada } \\
\text { pemberitahuan data yang } \\
\text { belum terisi. }\end{array}$ & $\checkmark$ & \\
\hline $\begin{array}{ll}\text { 3. } & \text { Form } \\
& \text { Data } \\
& \text { PNS }\end{array}$ & $\begin{array}{l}\text { Dapat tersimpan jika } \\
\text { semua data yang di-input } \\
\text { terisi dengan benar } \\
\text { tetapi jika data ada yang } \\
\text { kosong maka data tidak } \\
\text { dapat tersimpan data ada } \\
\text { pemberitahuan data yang } \\
\text { belum terisi. }\end{array}$ & $\sqrt{ }$ & \\
\hline
\end{tabular}


Tabel 3. Lembar Uji Coba Input Sistem (2)

\begin{tabular}{|c|c|c|c|}
\hline \multirow{2}{*}{$\begin{array}{c}\text { Nama Form } \\
\text { Input }\end{array}$} & \multirow{2}{*}{ Pengamatan } & \multicolumn{2}{|c|}{ Kesimpulan } \\
\hline & & Ya* & $\underset{\star}{\text { Tidak }}$ \\
\hline $\begin{array}{ll}\text { 1. } & \text { Form } \\
\text { Naik } \\
\text { Pangka } \\
t\end{array}$ & $\begin{array}{l}\text { Dapat tersimpan jika } \\
\text { semua data yang di- } \\
\text { input terisi dengan } \\
\text { benar tetapi jika } \\
\text { data ada yang kosong } \\
\text { maka data tidak dapat } \\
\text { tersimpan data ada } \\
\text { pemberitahuan data } \\
\text { yang belum terisi }\end{array}$ & $\checkmark$ & \\
\hline $\begin{array}{ll}2 . & \text { Form } \\
& \text { Mutasi } \\
& \text { PNS }\end{array}$ & $\begin{array}{l}\text { Dapat tersimpan jika } \\
\text { semua data yang di- } \\
\text { input terisi dengan } \\
\text { benar tetapi jika } \\
\text { data ada yang kosong } \\
\text { maka data tidak dapat } \\
\text { tersimpan data ada } \\
\text { pemberitahuan data } \\
\text { yang belum terisi }\end{array}$ & $\checkmark$ & \\
\hline
\end{tabular}

Tabel 4. Lembar Uji Coba Proses Sistem (3)

\begin{tabular}{|c|c|c|c|}
\hline \multirow{2}{*}{$\begin{array}{c}\text { Nama Form } \\
\text { Input }\end{array}$} & \multirow[b]{2}{*}{ Pengamatan } & \multicolumn{2}{|c|}{ Kesimpulan } \\
\hline & & Ya* & $\begin{array}{c}\text { Tidak } \\
\star\end{array}$ \\
\hline $\begin{array}{ll}\text { 1. } & \text { Form } \\
& \text { Pegawai } \\
& \text { Honorer }\end{array}$ & \begin{tabular}{lrr} 
Dapat & \multicolumn{2}{r}{ tersimpan } \\
jika & semua & data \\
yang & di-input \\
terisi & dengan benar \\
tetapi & jika & data \\
ada & yang & kosong \\
maka & data & tidak \\
dapat & tersimpan \\
data & \multicolumn{4}{c}{ ada } \\
pemberitahuan data \\
yang belum terisi
\end{tabular} & $\checkmark$ & \\
\hline $\begin{array}{ll}\text { 2. } & \text { Form } \\
\text { Cetak } \\
\text { SK }\end{array}$ & $\begin{array}{lrr}\text { Proses cetak } & \text { surat } \\
\text { Sk } & \text { tidak } & \text { ada } \\
\text { masalah dan tombol } \\
\text { cetak } & \text { berfungsi } \\
\text { sesuai } & & \end{array}$ & $\checkmark$ & \\
\hline
\end{tabular}

\section{Simpulan dan Saran}

\subsection{Simpulan}

Dengan adanya Rancang Bangun Aplikasi Kepegawaian Pegawai Negeri Sipil dan Pegawai Honorer pada Badan Kepegawaian dan Diklat Pemerintah Kabupaten Pesawaran yang menggunakan pendekatan Waterfall dan dibangun menggunakan bahasa pemograman Delphi serta basis data MySQL sebagai tempat penyimpanan dan pengelolaan data Pegawai Negeri Sipil dan Pegawai Honorer menjadi lebih efisien dibandingkan dengan sebelumnya yang masih menggunakan Microsoft Exel.

\subsection{Saran}

Berdasarkan simpulan dari hasil penelitian yang telah diuraikan, maka saran yang dapat diberikan untuk pengembangan lebih lanjut dari Rancang Bangun Aplikasi Kepegawaian Pegawai Negeri Sipil dan Pegawai Honorer pada Badan Kepegawaian dan Diklat Pemerintah Kabupaten Pesawaran, antara lain:
1. Perlu adanya pemeliharaan sistem serta penyempurnaanya, maka evaluasi dalam jangka waktu dibutuhkan, misalnya satu tahun atau lebih.

2. Evaluasi menyangkut kemungkinan pengembangan kembali fasilitas sistem yang disesuaikan dengan perkembangan dan kemajuan proses pengelolaan data pemohon.

\section{Daftar Pustaka}

[1] Ariyadi, 2010, Rancang Bangun Perangkat Lunak Tes Kompetensi Bidang Komputer Calon Pegawai Negeri Sipil (CPNS) Polri Berbasis Local Area Network, Universitas Islam Negeri Syarif Hidayatullah.

[2] Jogiyanto, HM, 2005, Analisis dan Desain Sistem Informasi, Penerbit Andi, Yogyakarta.

[3] Mahendra Yoga Purnama, 2011, Pembuatan Aplikasi Pengolahan Data Pegawai pada Disnakertranssos Kabupaten Boyolali dengan Menggunakan Netbeans 6.9, Amikom Yogyakarta.

[4] Nugroho, Bunafit, 2008, Latihan Membuat Aplikasi Web PHP dan MySQL dengan Dreamweaver MX $(6,7,2004)$ dan 8. Gava Media. Yogyakarta.

[5] Pressman, Roger S, 2010, Software Engineering A Practitioner's Approach Seventh Edition, Penerbit McGraw-Hill, New York.

[6] Santi Nasution, 2008, Sistem Informasi Pengolahan Data Gaji Pegawai pada Kantor Dinas Perikanan dan Kelautan Labuhan Ratu dengan Menggunakan Visual Basic 6.0, Universitas Sumatera Utara Medan.

[7] Shalahudin, Muhammad dan Rosa Ariani S. 2011. Modul Pembelajaran Rekayasa Perangkat Lunak Terstruktur dan Berorientasi Objek. Modula. Bandung.

[8] Teknokrat. 2014. Panduan Penulisan Laporan Praktek Kerja Lapangang (PKL). Tugas Akhir. Proposal dan Skripsi. Bandar Lampung.

[9] Undang-Undang nomor 43 tahun 1999 tentang Pokok - Pokok Kepegawaian, Jakarta, Presiden RI dan DPR RI.

[10] Undang-Undang nomor 21 tahun 2014 tentang Pemberhentian Pegawai Negeri Sipil, Jakarta, Presiden RI dan DPR RI. 